\title{
Euphausiid transport in the Western Arctic Ocean
}

\author{
L. Berline ${ }^{1, *}$, Y. H. Spitz ${ }^{1}$, C. J. Ashjian ${ }^{2}$, R. G. Campbell ${ }^{3}$, W. Maslowski ${ }^{4}$, S. E. Moore ${ }^{5}$ \\ ${ }^{1}$ College of Oceanic and Atmospheric Sciences, Oregon State University, Corvallis, Oregon 97331-5503, USA \\ ${ }^{2}$ Biology Department, Woods Hole Oceanographic Institution, Woods Hole, Massachusetts 02543, USA \\ ${ }^{3}$ Graduate School of Oceanography, University of Rhode Island, Narragansett, Rhode Island 02882-1197, USA \\ ${ }^{4}$ Oceanography Department, Naval Postgraduate School, Monterey, California 93943-5122, USA \\ ${ }^{5}$ NOAA/AFSC at APL-University of Washington, Seattle, Washington 98105, USA
}

\begin{abstract}
Euphausiids are commonly found in the stomachs of bowhead whales Balaena mysticetus hunted near Barrow, Alaska; however, no evidence exists of a self-sustaining population in this region. To explain euphausiid presence near Barrow, their transport from the northern Bering Sea was investigated through particle tracking experiments using velocity fields from an ocean general circulation model in 4 contrasted circulation scenarios (1997, 1998, 2002 and 2003). Euphausiids were released during their spawning season (April-June) in the bottom and surface layers in the northern Bering Sea, their endemic region, and tracked through the Chukchi-Beaufort Sea. Results show that both Anadyr Gulf and Shpanberg Strait are potential regions of origin for euphausiids. Topographically steered bottom particles have 4 to 5 times higher probability of reaching Barrow than surface particles (ca. $95 \%$ versus $20 \%$ of particles). As euphausiids are often found near the bottom on the northern Bering shelf, this suggests a very high probability of euphausiids reaching Barrow, making this location a privileged area for whale feeding. The main pathways to Barrow across the Chukchi Sea shelf are Central Valley (CV) and Herald Valley (HV). The transit to Barrow takes 4 to 20 mo. Arrivals at Barrow have 2 peaks at ca. $200 \mathrm{~d}$ (fall, CV particles) and $395 \mathrm{~d}$ after release (spring, mixed $\mathrm{CV}$ and $\mathrm{HV}$ ) on average, because of the seasonal cycle of the Chukchi Sea currents. Elevated euphausiid abundance in the fall at Barrow is favored by a high Bering Strait northward transport and by southerly winds, driving organisms through CV rather than through the HV pathway.
\end{abstract}

KEY WORDS: Euphausiid · Thysanoessa spp. · Bowhead whale $\cdot$ Balaena mysticetus $\cdot$ Western Arctic Ocean · Chukchi Sea · Lagrangian drifter · Zooplankton advection model

\section{INTRODUCTION}

The bowhead whale Balaena mysticetus is the only baleen whale that spends its entire life in cold northern waters (Moore \& Reeves 1993). The Bering-ChukchiBeaufort Seas population, the only one that has rebounded to significant numbers since commercial whaling ceased, migrates from its wintering grounds in the northern Bering Sea to its summer feeding grounds in the eastern Beaufort Sea (Moore \& Reeves 1993, Moore et al. 2000, George et al. 2004). Along this migration path on the Alaskan shores, native human populations have been hunting this whale for their subsistence for centuries. During their migration, whales stop to feed in regions where prey aggregates
(Lowry 1993, Lowry et al. 2004), therefore their spatial distribution is linked to prey abundance. The whale diet, known through the examination of stomach contents of whales harvested by Alaska natives, is mainly composed of copepods, euphausiids, amphipods and mysids (Lowry 1993, Lowry \& Sheffield 2002, Lowry et al. 2004), but the proportion of each prey differs in time and space. At Barrow, the frequency of occurrence of prey types shows seasonal variations. Copepods (especially Calanus glacialis and C. hyperboreus) are found more often in whales harvested in the spring, while euphausiids (Thysanoessa inermis and T. raschii) are found with similar frequency in autumn and spring (94 and $93 \%$ of stomach contents respectively, Lowry et al. 2004). Moreover, Lowry et al. (2004) noticed significant 
differences in the frequency of occurrence of prey types between whales harvested at Kaktovik (Beaufort Sea) and Barrow. Copepods occurred more often in whales harvested near Kaktovik, whereas euphausiids occurred more often near Barrow. At Barrow, euphausiids are also the dominant prey in terms of prey volume with 88 and $63 \%$ of the stomach volume in fall and spring respectively. Euphausiids are also commonly washed up on the shores near Barrow ( $\mathrm{S}$. Braund \& G. Divoky pers. comm.), and were reported in net tows north of Barrow (Johnson 1958, C. J. Ashjian \& R. G. Campbell unpubl. data).

Interestingly, there is no evidence that the euphausiids Thysanoessa raschii and T. inermis found in the stomachs of whales and seabirds near Barrow and in the Beaufort Sea reproduce there (Einarsson 1945, Johnson 1958, 1963, Niebauer \& Schell 1993, Siegel 2000a). Euphausiids in general are not believed to be endemic to the Arctic (e.g. Dalpadado \& Skjoldal 1996). However, a recent report of spawning of $T$. raschii in the Laptev Sea by Timofeev (2000) may indicate that this may no longer be the case. In contrast, the endemic copepods Calanus hyperboreus and $C$. glacialis, both important prey of bowhead whales, do have a complete life cycle in the Arctic. To be found near Barrow, euphausiids must be transported from elsewhere. One hypothesis is that the Chukchi Sea euphausiid stock could be maintained through the input of new individuals from the Bering Sea stock (Cooney \& Coyle 1982, Springer et al. 1989) via a path through the Bering Strait (Moore \& Clarke 1992, Moore et al. 1995, Moore et al. 2000, Lowry et al. 2004).

Thysanoessa inermis and T. raschii are endemic to the Bering and Okhotsk Seas, where they prevail in shallow waters (Ponomareva 1963). T. inermis is also found on the Bering Sea slope. In the northern Bering Sea, spawning occurs in April-May with $T$. inermis spawning before T. raschii (Ponomareva 1963, Siegel 2000a). The onset of spawning appears to be triggered by the spring phytoplankton bloom (Einarsson 1945, Ponomareva 1963, Astthorsson \& Gislason 1997). Development time from eggs to furcilia is 31 to $40 \mathrm{~d}$ for T. inermis in the Southern Bering Sea (Siegel 2000a). After a number of juvenile stages, Thysanoessa spp. may become mature at the end of the first or second year and live for 2 to 4 yr (Einarsson 1945, Wiborg 1971, Berkes 1976, Jorgensen \& Mathews 1975, Kulka \& Corey 1978, Falk-Petersen \& Hopkins 1981, Dalpadado \& Skjoldal 1991, 1996, Astthorsson \& Gislason 1997). Development time is increased in colder water farther to the north and spawning may not occur in the Arctic. After spawning, euphausiid biomass increases and peaks between June and September in the northern Bering Sea. Cooney (1981) reported significant numbers of $T$. raschii on the middle and coastal domain in the northeastern Bering Shelf. Ponomareva (1963) reported abundant $T$. raschii in Russian waters from the Sea of Okhotsk to the Anadyr Gulf $\left(200 \mathrm{mg} \mathrm{m}^{-3}\right.$ in May-June, 100 to $500 \mathrm{mg} \mathrm{m}^{-3}$ in the fall and an annual recorded maximum at 500 to $1000 \mathrm{mg} \mathrm{m}^{-3}$ ). In fall 2003 and 2004, T. inermis biomass greater than $250 \mathrm{mg} \mathrm{m}^{-3}$, along with T. raschii, was found in the Anadyr Gulf (North Pacific Anadromous Fish Commission 2004, 2005). Euphausiids are particularly abundant on the western Bering Shelf: Springer et al. (1989) reported $T$. raschii furcilia concentrations up to 10000 ind. $\mathrm{m}^{-2}$, i.e. $1000 \mathrm{mg} \mathrm{m}^{-2}$ in the Anadyr Strait in July 1985, compared to only 200 ind. $\mathrm{m}^{-2}$ in Shpanberg Strait. Planktivorous seabirds also feed preferentially in the western Bering Sea (Piatt \& Springer 2003). This significant euphausiid abundance in summer in the northwestern Bering Sea is associated with the 'Green Belt' (Springer et al. 1996), a highly productive zone that surrounds the Bering Shelf, and ends in the southern Chukchi Sea.

Three main currents (Coachman et al. 1975, Walsh et al. 1989, Weingartner et al. 2005) could advect euphausiids from the northern Bering Sea to the Chukchi Sea. In the western Bering Sea, cold and salty Anadyr waters originating in the Bering Slope Current turn north near Cape Navarin to become the Anadyr Current, flowing northward through Anadyr Gulf, Anadyr Strait, then crossing the Chirikov Basin and Bering Strait. North of the Bering Strait, Anadyr waters occupy the western half of the Chukchi Shelf. Bering Shelf waters, less salty and warmer, originating in the broad central Bering Shelf, reach the Bering Strait from both Anadyr and Shpanberg Straits. Close to the coast, on the eastern side of the Bering and Chukchi Seas, flows the warm and fresh buoyancy-driven Alaskan Coastal Current (ACC). North of the Bering Strait, Anadyr and Bering Shelf waters spread over the Chukchi Shelf and move northward, crossing the shelf through 3 main submarine valleys: Herald Valley in the west, Central Valley in the mid-Chukchi Sea, and Barrow Canyon in the east (Weingartner et al. 1998, Woodgate et al. 2005a). Part of the Barrow Canyon outflow may follow the Beaufort slope eastward and part may enter the Canada Basin to the north (Pickart et al. 2005).

Euphausiids have been reported on the Chukchi shelf (Moore et al. 1995, Schell et al. 1998). However, very few euphausiids were collected on the Chukchi Shelf (Lane et al. 2008, R. G. Campbell unpubl. data, S. L. Smith pers. comm.) during the Western Arctic ShelfBasin Interactions Project (SBI) (Grebmeier \& Harvey 2005) cruises in spring and fall 2002 and 2004 in the Chukchi Sea. These low numbers could be related to net avoidance, as most sampling was made during daylight and using vertical net tows. To establish the 
link between euphausiids encountered at Barrow and the Bering Sea populations, the potential transport paths and duration of euphausiids through the Chukchi Sea, especially during winter and spring, must be understood. In addition, the seasonal and interannual variations of this transport relative to changes in ice-cover and winds remain unknown. Finally, the potential relationships between euphausiid abundance and bowhead whale aggregation near Barrow have never been explored. These relationships can readily be addressed through biological-physical modeling of euphausiid transport through the Chukchi Sea.

The goal of this study is to achieve a better understanding of the transport of euphausiids from the Bering Sea to the Barrow region by simulating their trajectories under different scenarios of ocean circulation.

\section{MATERIALS AND METHODS}

To simulate the transport of euphausiids from the Bering Sea to Barrow, particles are released in the Bering Sea, and advected using velocity fields from an ocean general circulation model. Several release scenarios and circulation patterns are examined.

Velocity fields. Velocity fields are from a pan-Arctic ocean and sea-ice model simulation (see Maslowski et al. 2004 for details of the model setup), forced with realistic surface fluxes from 1979 to 2003. The regional model domain extends from the North Pacific, across the Arctic Ocean, to the North Atlantic, and is configured with a grid of $1 / 12^{\circ}(\sim 9 \mathrm{~km})$ horizontal resolution and 45 levels in the vertical. This simulation has been compared to observations for the northern Bering Sea (Clement et al. 2005) and shows a realistic overall representation of currents and water masses. The particle tracking domain, which is a subset of the entire domain, covers the northern Bering Sea, Chukchi Sea and western Beaufort Sea from approximately $60^{\circ} \mathrm{N}$ to $84^{\circ} \mathrm{N}$ and $140^{\circ} \mathrm{W}$ to $160^{\circ} \mathrm{E}$ (Fig. 1). Daily snapshot velocity fields at 2.5 and $22.5 \mathrm{~m}$ were used for the simulations.

Particle tracking. As a first approximation, euphausiids are considered as passive particles, with no horizontal motility and no growth/mortality. Euphausiid horizontal swimming speed is considered to be negligible relative to the horizontal current speed as no data on swimming ability are available for these species. Similar approaches were followed in other modeling studies (e.g. Hofmann et al. 1998, Murphy et al. 1998, Fach et al. 2002, Thorpe et al. 2004). Euphausiids are transported either at $2.5 \mathrm{~m}$ (surface) or $22.5 \mathrm{~m}$ (bottom). Taking the velocity at $22.5 \mathrm{~m}$ to estimate the near bottom velocity is a reasonable approximation according to observations (Woodgate et al. 2005a) and model outputs (not shown). Where the bottom is between 2.5 and $22.5 \mathrm{~m}$, particles stay at the deeper model depth following the local bathymetry,

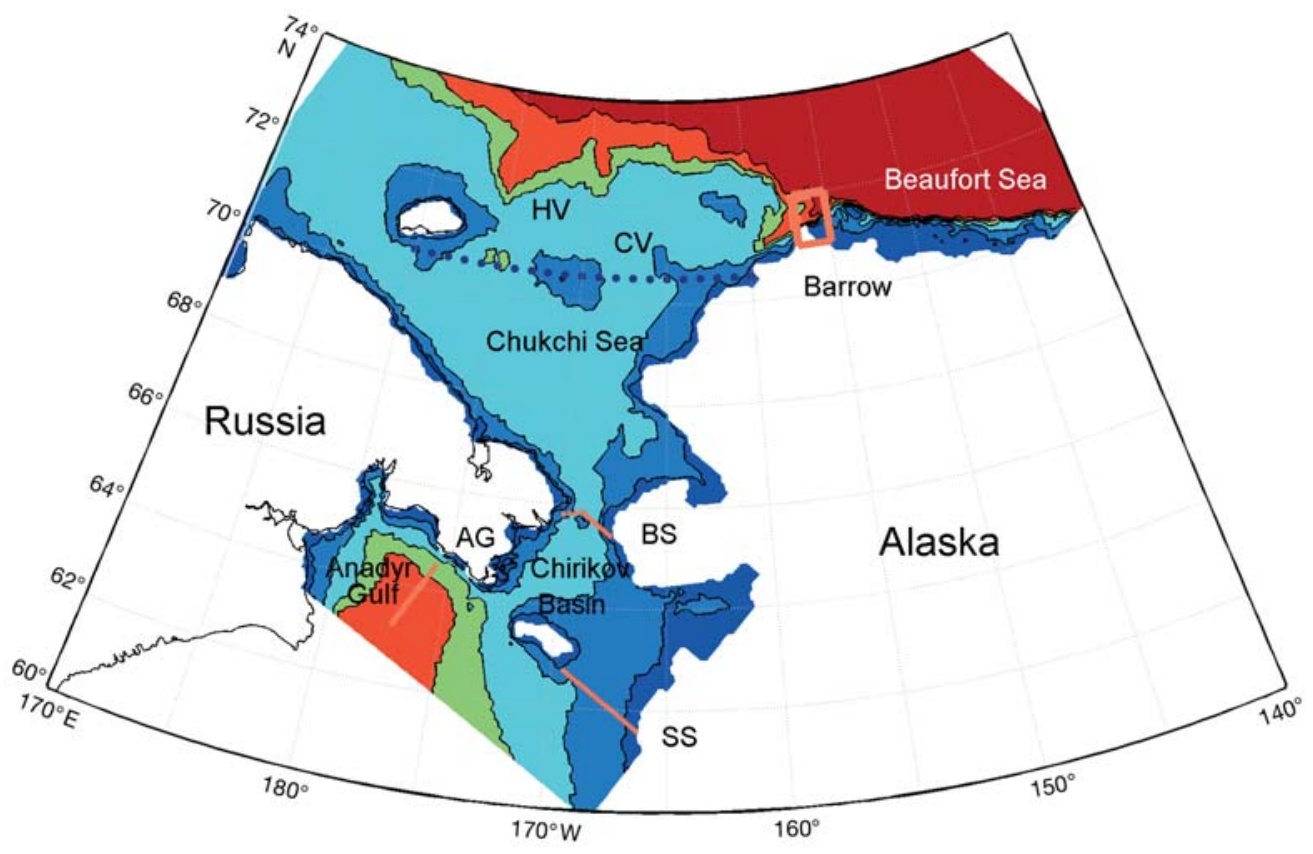

Fig. 1. Bathymetry of the model domain (filled contours at 15, 30, 45, 60, $100 \mathrm{~m}$ ) with boundaries of the Barrow region (red rectangle), and the 3 seeding locations (red lines): Anadyr Gulf (AG), Shpanberg Strait (SS), Bering Strait (BS). HV and CV indicate Herald Valley and Central Valley respectively. Blue dots along the $70.5^{\circ} \mathrm{N}$ parallel: section used for counting particles 
and vertically interpolated velocities are used. The offline horizontal advection of euphausiids is computed using the POP model predictor-corrector scheme (code available at http://climate.lanl.gov/Models/POP/, Smith \& Gent 2004) with a $2 \mathrm{~h}$ time-step. The daily output velocities are linearly interpolated in time.

Since euphausiid diel vertical migrations have been observed in regions other than our studied area (Siegel 2000b), simulations with diel vertical migration (DVM) (particle at the surface when dark and at the bottom when light, following the annual cycle of daylight) were also conducted. Results are briefly discussed here because they are generally intermediate between the results of surface and bottom simulations.

When a particle crosses an open boundary of the domain, it is lost from the simulation. At the land boundaries, the circulation model used a no-slip lateral boundary condition, which means that the velocity is zero at the land-water interface. This condition tends to slow down particles when they come close to the coast or near the bottom, and possibly trap them, referred to as 'landing'. At the bottom, landing is prevented by moving the particle to the next upper level if it approaches land. At the surface, landing can occur. A trapped particle can move away from the coast if the current becomes favorable. If a particle is trapped (i.e. displacement smaller than 0.001 degree) at the coast for more than $3 \mathrm{~d}$, it is considered as 'landed' and its trajectory is discarded from the analysis. This criterion was chosen to compensate for the artificial zero velocity at the coast (no-slip condition) while excluding trajectories from particles that landed for a long time. Varying this criterion from 1 to $5 \mathrm{~d}$ does not significantly change the results.

Seeding and circulation scenarios. Seeding locations were chosen to study the origin of euphausiids and the timing of their transit to Barrow. Particles are seeded at 3 different locations: Anadyr Gulf (AG), Shpanberg Strait (SS) and Bering Strait (BS) (Fig. 1). BS was chosen in addition to AG and SS to represent euphausiids originating in the Chirikov Basin, closer to the Chukchi Sea than AG and SS, and with a uniform east-west distribution. Table 1 summarizes the number of particles released at each location. The release period covers only the spawning period, i.e. from April to June for Thysanoessa raschii and T. inermis. The years 1997, 1998, 2002 and 2003 were chosen for the simulations. On average, ice cover was at a maximum in March, with the ice edge around $64^{\circ} \mathrm{N}$, and reached a minimum in September with the ice edge near $73^{\circ} \mathrm{N}$. Years 1997, 2002 and 2003 had low ice cover, while ice cover in 1998 was average. The Arctic Oscillation (Thompson \& Wallace 1998), the main mode of variability of the sea level pressure in the region, was mostly positive in 2002 to 2003 (weak northeasterly
Table 1. Number of particles released for the 3 seeding locations (see Fig. 1) and the 2 depths (1 particle per grid point of each section)

\begin{tabular}{|lccc|}
\hline & AG & SS & BS \\
\hline Surface & 1656 & 2208 & 1196 \\
Bottom & 1656 & 1380 & 1196 \\
\hline
\end{tabular}

winds), and negative in 1997 to 1998 (strong northeasterly winds). Because of this interannual variability, the impact of wind forcing and ice cover variability on the transport can be analyzed using these 4 differing conditions of ocean circulation, winds and sea-ice cover.

Three-year simulations with repeated same-year circulation were conducted for the 4 circulation scenarios and the 3 seeding locations (a total of 12 simulations). Particles were released during the spawning period (April-June) of the first year and tracked through Year 3. At the end of the simulations, no more particles are reaching Barrow and therefore the $3 \mathrm{yr}$ period is appropriate to calculate the probability of arrival at Barrow. Hereinafter, the simulations are referred to according to the seeding location and the year of the simulation (e.g. AG97 for Anadyr Gulf 1997).

\section{RESULTS}

A particle is considered to arrive at Barrow when it enters the region defined by the red rectangle on Fig. 1, defined according to the area of whale sighting near Point Barrow (Moore \& Reeves 1993) covering $71-72^{\circ} \mathrm{N}, 155-157^{\circ} \mathrm{W}$. For each simulation, trajectories crossing the Barrow region are counted and identified, as well as trajectories ending on land. As the $1 / 12^{\circ}$ resolution and stair-like representation of bathymetry does not allow an accurate simulation of some of the coastal and near shore processes, landing locations are not analyzed further.

\section{Pathways to Barrow}

The main pathways to Barrow are identified by analyzing the distribution of particles crossing the section at $70.5^{\circ} \mathrm{N}$ (Figs. 2 to 4 ). At the surface, the majority of AG97 particles reaching Barrow cross latitude $70.5^{\circ} \mathrm{N}$ near longitude $166^{\circ} \mathrm{W}$ (Fig. 2, top), corresponding to CV (see bathymetry on Fig. 1). For AG02 (Fig. 3, top), $\mathrm{CV}$ is still the main pathway for particles, but secondary pathways also exist at $171^{\circ} \mathrm{W}$ and at $163^{\circ} \mathrm{W}$ along the Alaskan coast. At the bottom, the majority of particles flow through CV in AG97, while both the CV and HV $\left(173-175^{\circ} \mathrm{W}\right)$ pathways and a coastal pathway at 

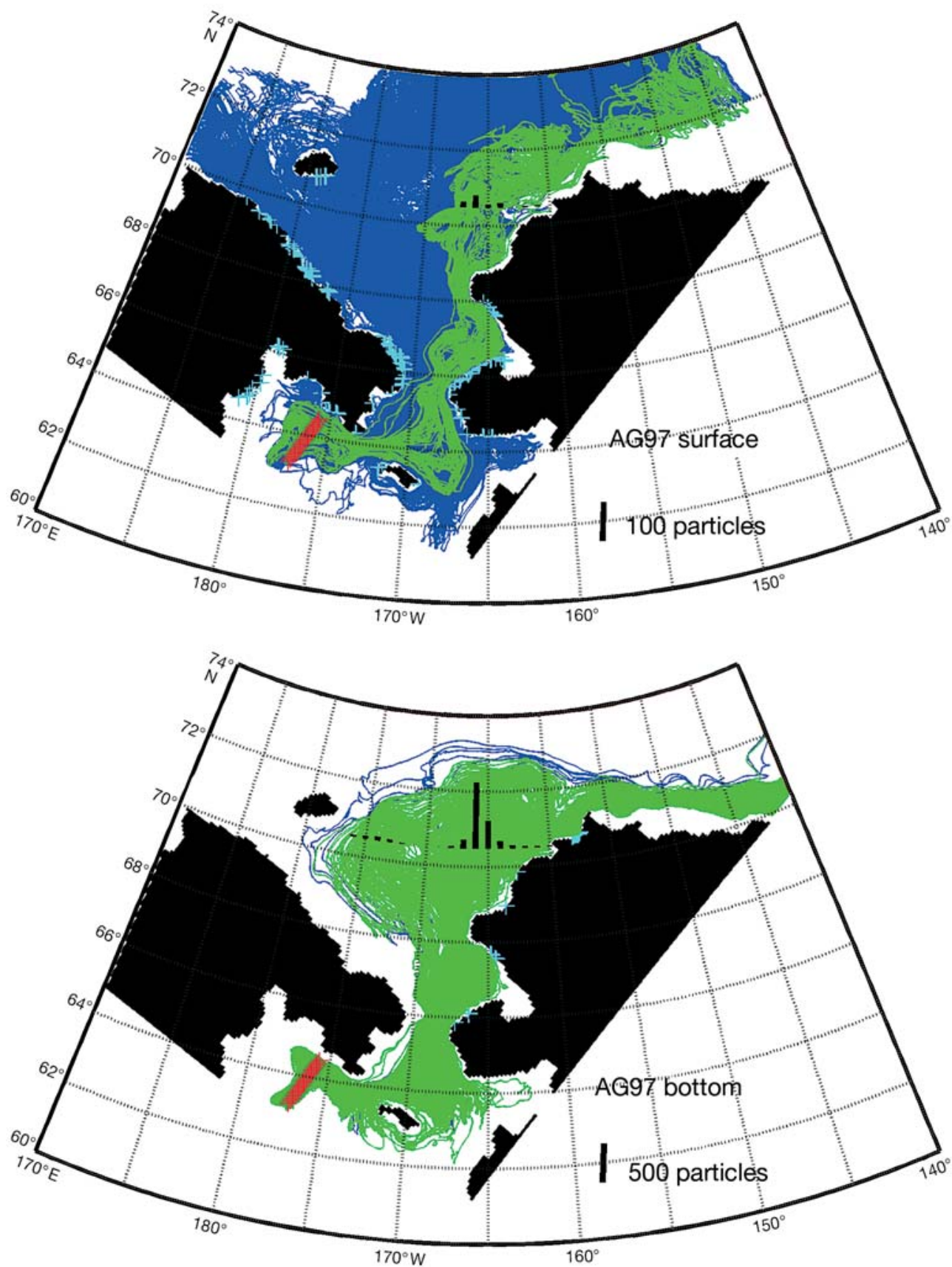

Fig. 2. AG97 (seeding location AG, year 1997) trajectories for surface (top) and bottom (bottom) seeding. The sum of these numerous lines appear as a solid patch. (-) Trajectories that do not reach Barrow, (-) trajectories that do reach Barrow, (+) landed drifters, and (+) AG seeding location. The length of the black bars along the $70.5^{\circ} \mathrm{N}$ parallel is proportional to the number of trajectories crossing this latitude at this longitude $\pm 1 / 2^{\circ}$. Scale bar on bottom right

$164^{\circ} \mathrm{W}$ are observed in AG02. Over the 4 circulations scenarios (trajectories for 1998 and 2003 not shown for clarity), the main surface pathway is through CV, while the main bottom pathways are CV and HV. Apart from these main routes, secondary pathways along the Alaskan coast or over Herald shoal are possible. North of the $70.5^{\circ} \mathrm{N}$ line, trajectories divide to the north or south of Hanna shoal $\left(162^{\circ} \mathrm{W}, 72^{\circ} \mathrm{N}\right)$ for both $\mathrm{CV}$ and HV particles. These results show that both surface and bottom layer circulation on the shallow Chukchi Sea are strongly impacted by bottom topography. The 2 main pathways, $\mathrm{HV}$ and $\mathrm{CV}$, are consistent with the largest transport pathways determined from observations (Weingartner et al. 2005, Woodgate et al. 

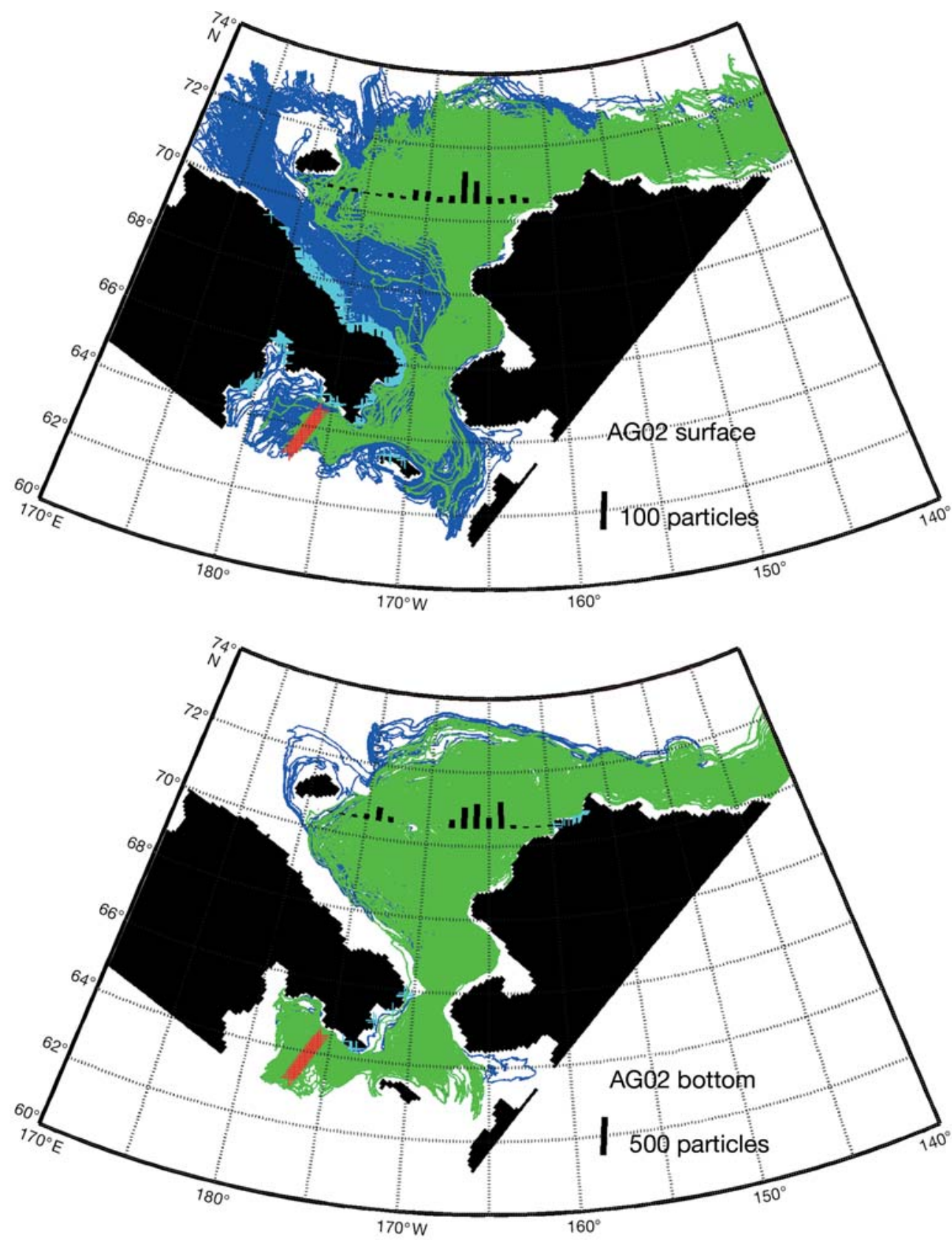

Fig. 3. AG02 trajectories. Details as in Fig. 2

2005a). In addition, there is still a significant interannual variability in the importance of each pathway, and in the abundance of particles reaching Barrow (see 'Interannual variability of euphausiid transport').

Trajectories from SS and AG seeding locations are compared for the year 1997 (Figs. 2 \& 4). For surface particles, trajectories from AG and SS both explore the region up to $74^{\circ} \mathrm{N}$ and farther (Figs. $2 \& 4$, top panel). AG particles spread across the entire Chirikov Basin, contrary to SS particles that do not spread westward. Particles not reaching Barrow accumulate in the west- ern half of the Chukchi Sea, continue westward to the East Siberian Sea through Long Strait (between Wrangel Island and Russia), or northward to the Canada Basin. SS particles tend to stay closer to the Alaskan coast. For bottom trajectories (Figs. 2 to 4 bottom), SS particles flow essentially northward to reach the Bering Strait, and then stay on the eastern side of the domain, close to the coast. SS particles occupy only the eastern part of the Bering Strait, and rarely flow through HV, while AG particles occupy a wider part of the strait and commonly flow through HV. 

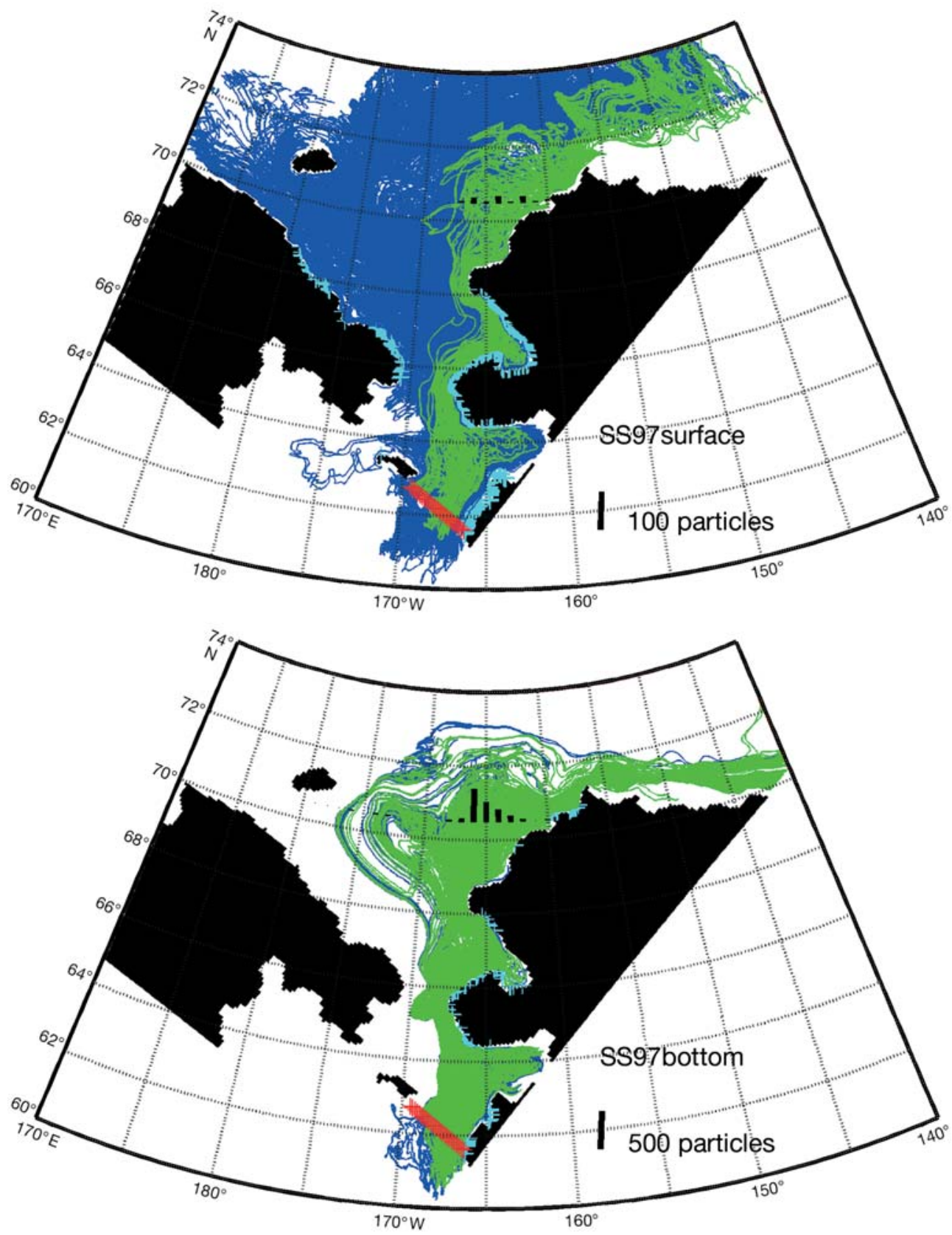

Fig. 4. SS97 trajectories. Details as in Fig. 2

The probability of a particle reaching Barrow with respect to its origin (AG or SS) is computed for the 4 circulation scenarios. The probability is computed as the number of particles having reached Barrow at the end of the simulation divided by the number of nonlanded particles, since landing is not considered as a realistic process. For the surface simulations, $20.4 \pm$ $26.0 \%$ (mean over the 4 circulation scenarios \pm SD) of AG particles reach Barrow vs. $24.0 \pm 22.5 \%$ for SS. Landing of surface particles along the Alaskan coast potentially reduces the probability of arrival at Barrow.
However, if we consider that all particles landed along the Alaskan coast would have reached Barrow, probabilities of arrival are not very different $(23.0 \pm 26.5 \%$ and $36.2 \pm 18.5 \%$ for AG and SS respectively). For bottom simulations, $96.0 \pm 6.3 \%$ of AG particles reach Barrow and $94.6 \pm 6.5 \%$ of SS particles. For surface and bottom simulations together a total of $68.9 \pm 41.5 \%$ of AG and $62.2 \pm 38.1 \%$ of SS particles reach Barrow. The difference between these probabilities is not statistically significant (ANOVA), therefore a particle found at Barrow has an approximately equal probabil- 
ity (68.9 versus $62.2 \%$ ) of having originated in the AG or in the SS regions. For the simulations with DVM (not shown), the probability of reaching Barrow is higher for SS particles than for AG particles (58.4 $\pm 6.0 \%$ against $38.7 \pm 22.4 \%$ respectively), but is still not significantly different. However, evidence of higher euphausiid abundance in AG compared to SS (more than an order of magnitude in July 1985, Springer et al. 1989) suggest that AG is the dominant source region for euphausiids at Barrow.

The difference between the bottom and surface trajectories is striking. Bottom particles occupy a smaller part of the domain (Figs. 2 \& 3, bottom panel), and do not drift westward or northward in contrast to the surface ones. The larger spatial extent of the surface trajectories compared to the bottom ones results from the higher variability of the surface currents and the weaker topographic steering. Also, mean winds from the northeast may create a westward mean Ekman current at the surface, turning northwestward and then northward in the subsurface region, preventing bottom particles from reaching the western part of the Chukchi Sea. To the east of Barrow, bottom particles follow the shelf break toward the eastern Beaufort Sea, while surface particles can take a northwesterly path (in 1997, 1998 not shown). Simulations with DVM (not shown) produced trajectories with a spatial distribution intermediate between surface and bottom trajectories, but no new pathways were obtained. Also striking is the much higher probability of bottom particles reaching Barrow compared to surface particles for all seeding locations (e.g. for AG seeding, the probability of reaching Barrow is 20.4 and $96.0 \%$ for surface and bottom particles respectively). Barrow is therefore the main final outflow region for bottom euphausiids from the Bering Sea, making it a privileged area for whale feeding. In contrast, the majority of surface particles do not reach Barrow, but end in the East Siberian Sea, the Canada Basin, or land on the southern Chukchi Sea coasts. Landing along the northern Chukotka coast is favored by the seasonal reversal of the East Siberian Current (data not shown).

While there are no data on euphausiid depth distribution in the Chukchi Sea, several factors support a bottom preference for euphausiids. In the Bering Sea, Thysanoessa raschii and T. inermis furcilia stay between the surface and $50 \mathrm{~m}$, while juveniles prefer deeper layers (50 to $100 \mathrm{~m}$, Ponomareva 1963). Since the depth of the Chukchi shelf is less than $60 \mathrm{~m}$, this suggests that juveniles would stay close to the bottom. Vertical migration to the surface to feed when it is dark should occur during the night, or under ice. However, the major euphausiid prey in summer (diatoms and other phytoplankton) are more abundant in the subsurface than at the surface (mean depth of the deep chlorophyll maximum is $27 \mathrm{~m}$ in summer, Hill \& Cota 2005). In spring, the depth of maximum chlorophyll is closer to the surface $(10 \mathrm{~m}$, Hill \& Cota 2005) but chlorophyll concentration does not change much between surface and $20 \mathrm{~m}$. Therefore, in spring and summer, euphausiids would be found preferentially at depths of 20 to $50 \mathrm{~m}$, consistent with Moore et al. (1995) observations near the Chukotka coast. During dark months of fall, winter and spring, observations made by Ponomareva (1963) in Anadyr Gulf in winter suggest that euphausiids stay close to the bottom and do not feed, living on their lipid reserves. Therefore, we focus on bottom simulations which seem more biologically realistic than surface or DVM simulations.

\section{Transit duration and age of euphausiids at Barrow}

One question central to this study is the duration of the euphausiid transit from the source region to Barrow and its variation with time. This transit time should be sufficiently short to be within the life span of a euphausiid so that individuals from the Bering Sea would survive until reaching Barrow. The transit time also determines the age of euphausiids found at Barrow, and the timing of arrivals in relation to the whale migration. Since euphausiids have been observed from Anadyr Gulf to the eastern Bering shelf, including the Chirikov Basin, we assume that euphausiids spawn in these 3 regions. The AG and SS particle release covers April to June, while BS release only covers May to June, coincident with the average timing of ice retreat. In order to identify the particles reaching Barrow, 3 main pathways were defined. Particles crossing the $70.5^{\circ} \mathrm{N}$ line between $180^{\circ} \mathrm{W}$ and $171^{\circ} \mathrm{W}$ are classified $\mathrm{HV}$, those crossing between $171^{\circ} \mathrm{W}$ and $165^{\circ} \mathrm{W}$ are $\mathrm{CV}$, and those to the east of $165^{\circ} \mathrm{W}$ are coastal current (CC).

Dates of particle arrival at Barrow are plotted against the seeding dates for the 3 seeding regions and the 4 circulation scenarios (Fig. 5). Fig. 5 shows both the time distribution of arrivals and the duration of the transit. Since arrivals during the third year are rare, only the first $2 \mathrm{yr}$ are considered. Focusing on arrival dates for the AG simulations, 2 groups are identified. A first group of fast particles arrives from September to December (Year 1 group), 4 to 8 mo after the seeding. They are mostly CV particles, and few CC. A second group arrives the following year (Year 2 group), and is less homogeneous, with CV, $\mathrm{HV}$ and CC particles, HV particles being the slowest. Between these 2 groups, there is a period with no arrivals that covers approximately November to January, corresponding to the lowest northward trans- 

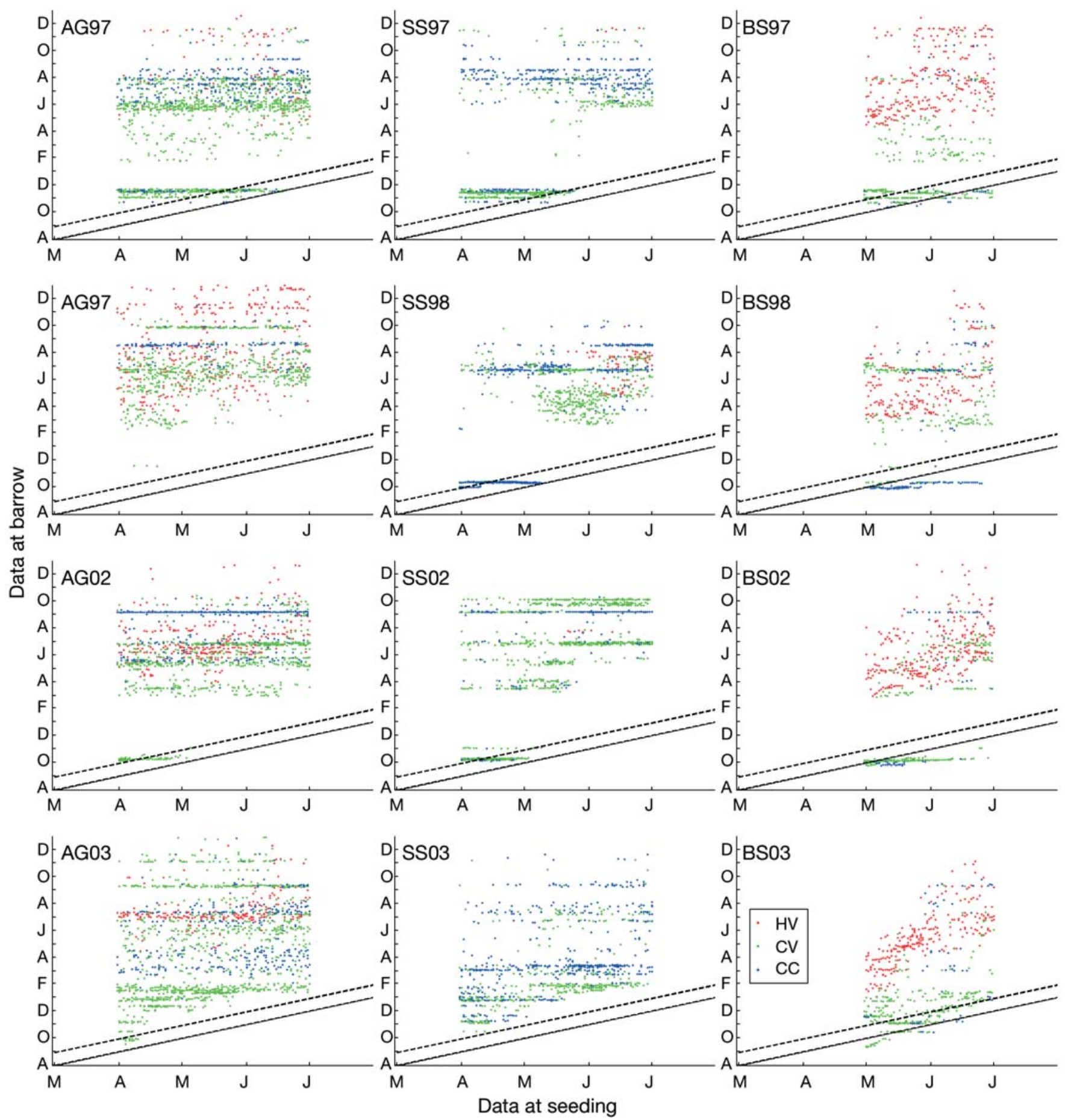

Fig. 5. Dates of arrival of bottom particles at Barrow vs. dates of release at the seeding locations: AG (left), SS (middle) and BS (right). Only the first 2 yr are plotted (March Year 1 to December Year 2). Dot color indicates particle pathway: green, CV; red, HV; blue, CC. (-) transit durations of 5 and 6 mo. Note that the y-axis label interval is 2 mo

port season. 2003 is an exception, with euphausiids arriving continuously. Arrivals peak in September to November and May to June for BS, and approximately 1 mo later for AG and SS. Arrivals are intermittent, e.g. particles seeded in June can arrive at the same time or earlier than particles seeded in April. Intermittency is in part due to the increasing velocity of the flow from spring to summer, and in part to coastal recirculation that traps and releases particles intermittently. The BS simulation has more 
particles going through HV (Fig. 5, red dots) because the western part of Bering Strait is more populated than with a seeding at AG or SS. Conversely, the SS simulation has more particles following the CC path (blue dots) because the eastern part of Bering Strait is more populated than with seeding at AG and BS. Table 2 summarizes the travel duration for the 2 arrival groups in each simulation. For the first group, the average transit lasts 146 to $192 \mathrm{~d}$ for the BS particles and 201 to $240 \mathrm{~d}$ (ca. 6 to $7 \mathrm{mo}$ ) for the AG particles. The first group from SS travels significantly faster than the first group from AG ( $t$-test: $p<0.01)$, because of the larger number of particles going through $\mathrm{CV}$ and $\mathrm{CC}$, a faster route on average than through HV. For the more temporally broad second group, the average transit time is 361 to $412 \mathrm{~d}$ (ca. 12 to $14 \mathrm{mo}$ ) for particles originating in the BS and 401 to $445 \mathrm{~d}$ for particles from the AG. The results for SS originating particles are generally similar to those for AG. As the distance from BS to Barrow is shorter than AG to Barrow, particles seeded at BS have shorter transit duration (up to $50 \mathrm{~d}$ less) than those seeded at AG.

The variations of transit times throughout the year also imply variations of the euphausiid age composition at Barrow (Figs. 6 to 8). The Year 1 group is made of furcilia and juvenile stages less than 8 mo old (Figs. 6 to 8, white bars), while the Year 2 group represents older juveniles and possibly adults (Figs. 6 to 8 , black bars). This grouping corresponds roughly to sexual maturity, assuming sexual maturation occurs at the end of the first year. There is, however, no consensus among authors on the maturation time (Einarsson 1945, Wiborg 1971, Berkes 1976, Jorgensen \& Matthews 1975, Kulka \& Corey 1978, Falk-Petersen \& Hopkins 1981, Dalpadado \& Skjoldal 1991, 1996, Astthorsson \& Gislason 1997) and no data are available for the Chukchi Sea. For all 3 seeding locations, spring euphausiids are only comprised of the Year 2 group, while fall euphausiids are a mix of Year 1 and Year 2 (from previous year), with Year 1 more abundant in late fall (Figs. 6 to 8). SS simulations produce higher Year 1 euphausiid abundance in the fall than AG simulations, partly because of shorter transit times (see Fig. 5). Both furcilia and juvenile euphausiids (ca. 2 to 24 mo old) were collected in zooplankton net tows and washed up on the shores at Barrow in September 2005 and 2006 (C. J. Ashjian \& R. G. Campbell unpubl. data, S. Braund \& G. Divoky pers. comm.), consistent with the simulations. However, to confirm that spring euphausiids are older than those in the fall, we will need accurate stage and size data from stomach content analysis of the whales harvested in the spring. These data would also confirm that euphausiids are overwintering successfully in the Chukchi Sea, since spring euphausiids must be born the previous year south of Bering Strait.

A 4 mo transit time from Bering Strait to either Barrow Canyon or Herald Valley was estimated by Woodgate et al. (2005a) using central Chukchi Sea mean velocity and the $600 \mathrm{~km}$ distance between those points. The mean velocity was derived from mooring measurements at $9 \mathrm{~m}$ above the bottom. The same calculation using the model simulation leads to a ca. 6 mo transit time. Comparison of the annual mean modeled and observed velocities at the same locations and the same depth as from the central Chukchi Sea moorings MC 2, 3, 4 (located respectively at $68^{\circ} 20.50^{\prime} \mathrm{N}$, $172^{\circ} 29.80^{\prime} \mathrm{W}_{\text {; }} 68^{\circ} 36.70^{\prime} \mathrm{N}, 171^{\circ} 4^{\circ} 40^{\prime} \mathrm{W}$; $68^{\circ} 51.40^{\prime} \mathrm{N}$, $169^{\circ} 35.60^{\prime} \mathrm{W}_{\text {; }}$ Woodgate et al. 2005a) for 1997, 1998, 2002 and 2003 shows that the model simulations underestimate the velocity at the bottom by ca. $25 \%$. Therefore, assuming that the velocities are consistent from $22.5 \mathrm{~m}$ to the bottom at these locations, the transit duration could be $25 \%$ shorter and more particles coming from AG could reach Barrow in the fall. Since simulation and observation periods are different, the interannual variability might explain part of this discrepancy.

In summary, euphausiid transit lasts from 4 to $>20 \mathrm{mo}$, with a first period of arrivals peaking in the fall, a period with no arrival, and then a second, longer period of arrival that peaks in the spring-early summer. This annual cycle is related to the northward volume transport cycle, maximum in summer-fall and minimum in winter-spring (Woodgate et al. 2005a,b), and to the pathway chosen (HV vs. CV or CC). If a particle has not yet reached Barrow in November by following either a too long or a too slow track, it will encounter low and variable currents in winter-spring that will delay its arrival to the next summer. The seasonal change in current magnitude and variability is responsible for this 'railway-crossing' effect for the particle arrivals.

Table 2. Mean transit duration $\pm 1 \mathrm{SD}$ (d) for BS, AG, and SS bottom simulations, for the first group (transit duration less than $8 \mathrm{mo}$ ) and the second group of arrivals (transit duration greater than 8 months and less than $20 \mathrm{mo}$ )

\begin{tabular}{|c|c|c|c|c|c|c|}
\hline \multirow{2}{*}{ Scenario } & \multicolumn{2}{|c|}{$=\mathrm{AG}$} & \multicolumn{2}{|c|}{$-\mathrm{SS}$} & \multicolumn{2}{|c|}{ BS } \\
\hline & Group 1 & Group 2 & Group 1 & Group 2 & Group 1 & Group 2 \\
\hline 1997 & $201 \pm 20$ & $401 \pm 54$ & $202 \pm 14$ & $426 \pm 54$ & $183 \pm 18$ & $412 \pm 82$ \\
\hline 1998 & $239 \pm 6$ & $445 \pm 66$ & $181 \pm 10$ & $380 \pm 50$ & $169 \pm 14$ & $377 \pm 62$ \\
\hline 2002 & $201 \pm 8$ & $415 \pm 60$ & $178 \pm 10$ & $429 \pm 61$ & $146 \pm 11$ & $373 \pm 54$ \\
\hline 2003 & $240 \pm 25$ & $404 \pm 91$ & $244 \pm 21$ & $362 \pm 75$ & $192 \pm 25$ & $361 \pm 71$ \\
\hline
\end{tabular}



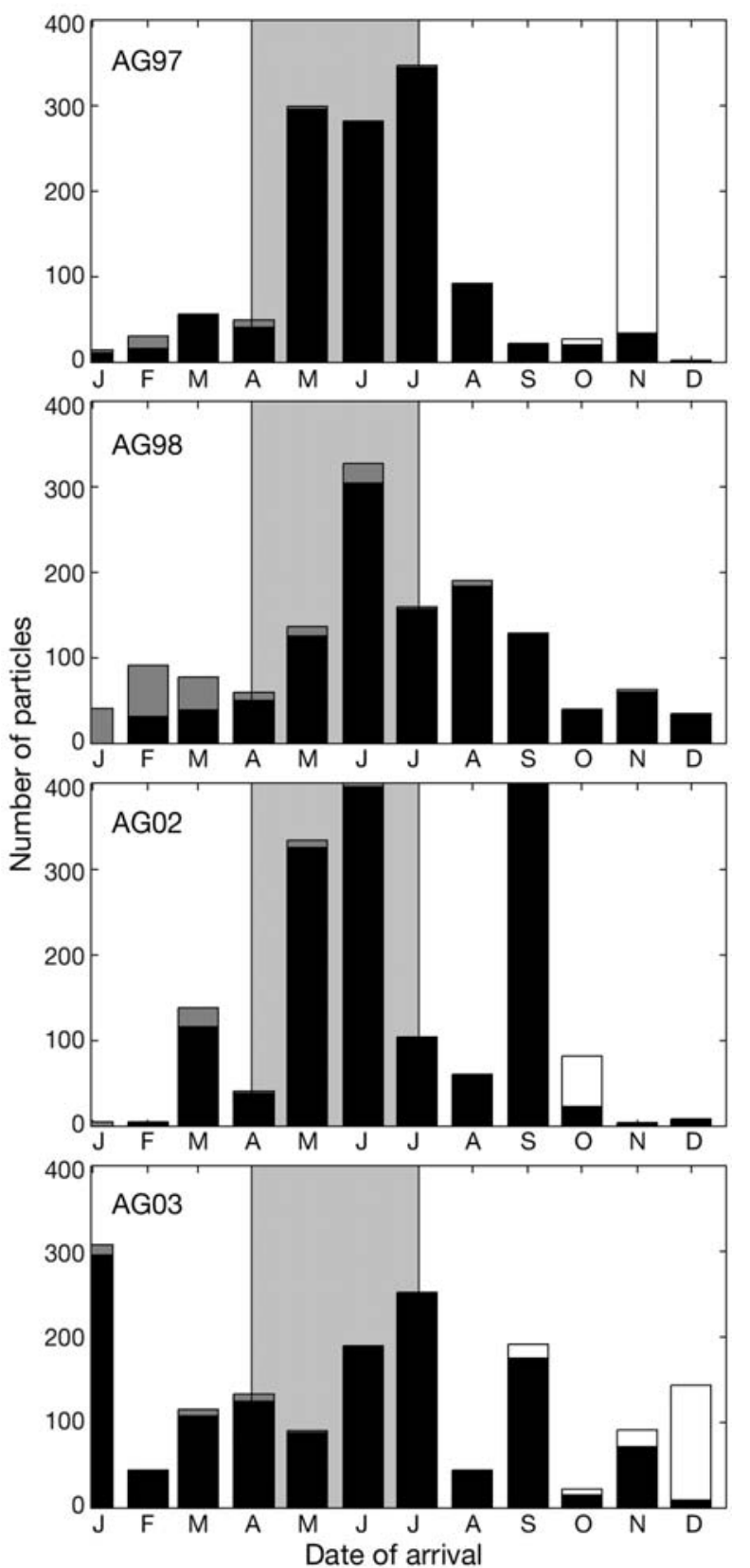

Fig. 6. Number of particles arriving each month at Barrow for the 4 circulation scenarios $(1997,1998,2002$ and 2003) and simulation AG. Background shaded area indicates the seeding period. white bars: particles arriving during Year 1 (Year 1 group); black bars: Year 2 arrivals; grey bars: Year 3 arrivals

\section{Interannual variability of euphausiid transport}

The simulations showed significant interannual variations in the transport pathways and the number of particles arriving at Barrow (Figs. 2 to 4). Here we try to identify the factors driving these variations. While the total number of bottom particles arriving at Barrow dur-
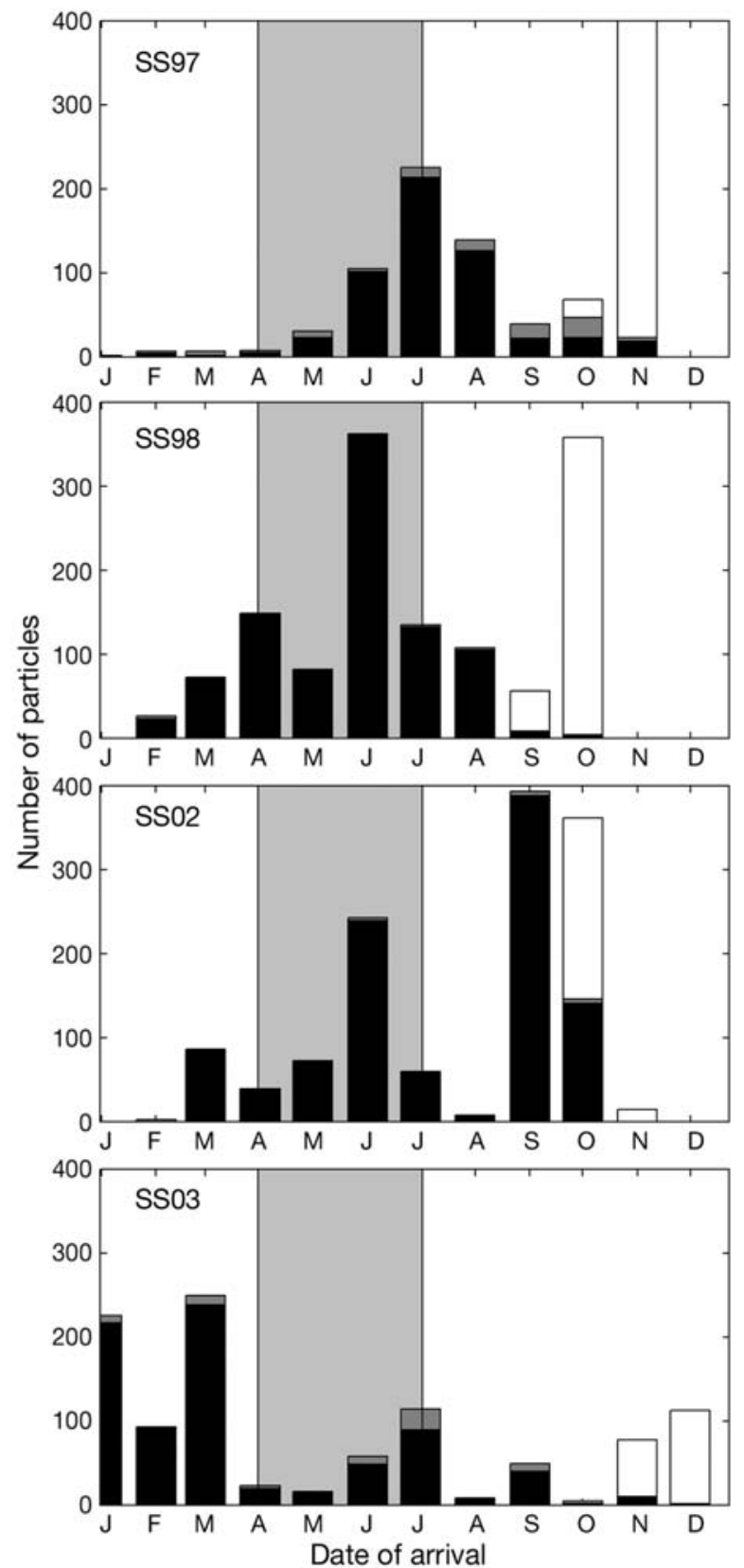

Fig. 7. Number of particles arriving in simulation SS. Details as in Fig. 6

ing the 3 yr of simulation shows little variation (ca. $20 \%$, Table 3a), the arrival dates do vary substantially. Taking the bowhead whale point of view, we focus on the abundance variations in April to May and September to October (hereinafter spring and fall), when most whales are migrating past Barrow. Fall euphausiid arrivals are concentrated in time by the large northward transport in summer-fall, and show large interannual variations; conversely, spring arrivals are more broadly distributed in time and more steady (Table $3 b$ ). In order to analyze the abundance of Year 1 euphausiids arriv- 


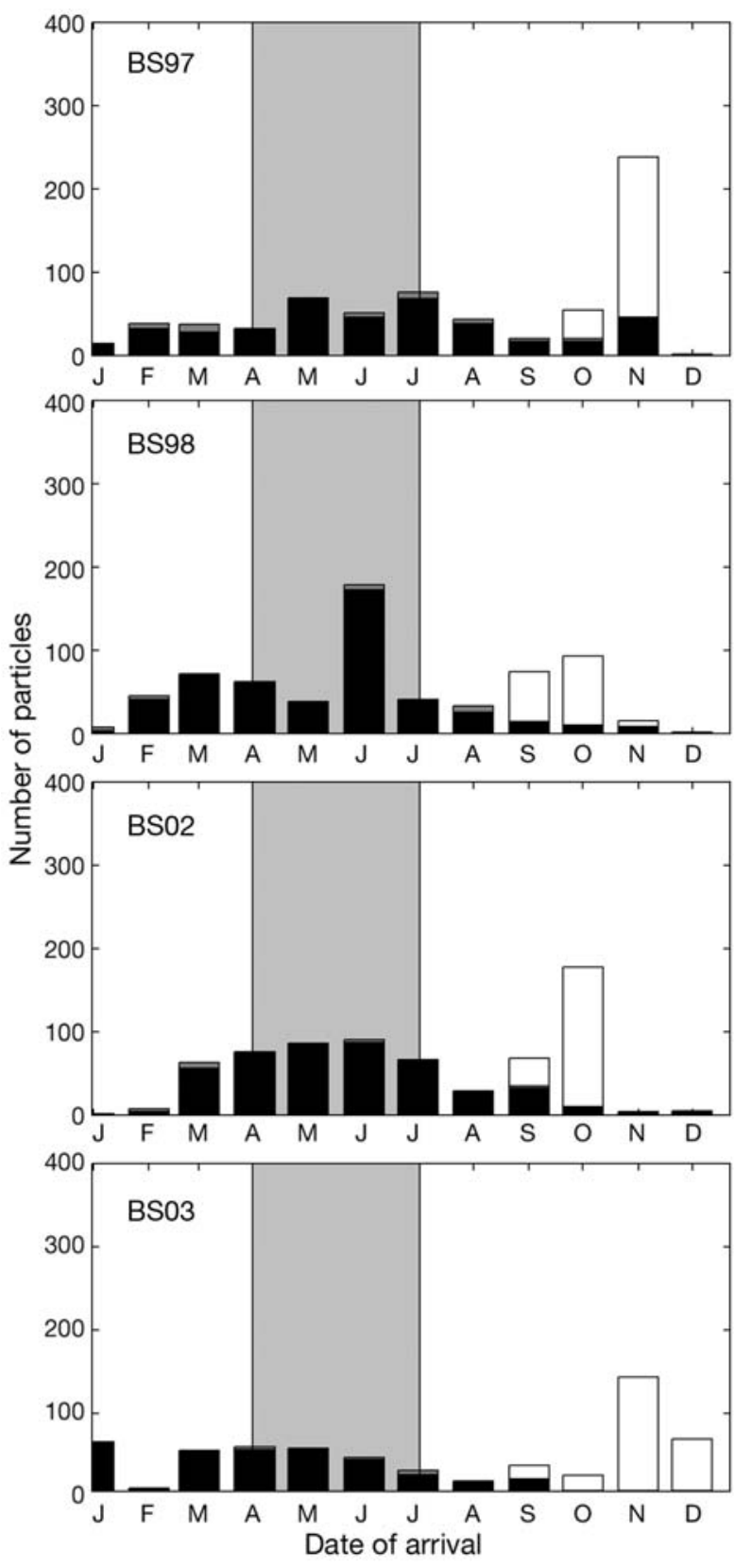

Fig. 8. Number of particles arriving in simulation BS. Details as in Fig. 6

ing in the fall (Table 4), we focus on the BS simulations for which Year 1 euphausiids are abundant. Schematically, 2 main factors can impact prey abundance in September-October: (1) the northward transport from the release date to the arrival date, because of the aforementioned railway-crossing effect that delay particles after November; and (2) the ratio of $\mathrm{CV}+\mathrm{CC}$ vs. $\mathrm{HV}$ particles, $\mathrm{CV}$ and $\mathrm{CC}$ being the only pathways that al- low particles to arrive in the fall following the spawning. According to the simulations in the fall, euphausiid abundance at Barrow is high in 1998 and 2002, whereas abundance is low in 1997 and 2003 (Table 4).

Let us take the Bering Strait transport as a proxy for the northward transport and analyze its effect on abundance. Indeed, current velocities at the Bering Strait are consistent with velocities in the southern half of the Chukchi Sea (Woodgate et al. 2005a). The fall euphausiid abundance increases with the mean Bering Strait transport for the May-October period (Table 4); however, abundance in 1998 would be higher than in 2002 if Bering Strait transport alone was driving the abundance. The lower abundance in 1998 relative to 2002 despite the higher transport at Bering Strait in 1998 can be explained by 2 causes: (1) the transport from $20 \mathrm{~m}$ to the bottom is not very different between the 2 yr (Table 4), and (2) more trajectories are trapped into the East Siberian Current, going westward through Long Strait (data not shown). In 2002, some particles from the western side of the Bering Strait join the CV pathway, which falls under cause (2). According to observational studies, the northward transport through Bering Strait and in a large part of the eastern Chukchi Sea can be partly explained by the local wind forcing (Aagaard et al. 1985, Roach et al. 1995, Woodgate et al. 2005a). Using our 4 yr of wind stress used to force the model, the local wind stress best correlating component (heading $14^{\circ}$ true) can explain $60 \%$ of the monthly Bering Strait transport variance, the transport being higher when the southward wind stress counteracting the flow is lower. Therefore, either the April to October Bering Strait transport or the local

Table 3a. Total number of bottom particles reaching Barrow during the $3 \mathrm{yr}$ of simulation for AG and BS seeding. $\mathrm{N}$ is the total number of particle seeded

\begin{tabular}{|lccc|}
\hline Scenario & AG & SS & BS \\
& $N=1656$ & $N=1380$ & $N=1196$ \\
\hline 1997 & 1631 & 1082 & 673 \\
1998 & 1347 & 1346 & 658 \\
2002 & 1593 & 1275 & 672 \\
2003 & 1321 & 1029 & 617 \\
\hline
\end{tabular}

Table 3b. Number of bottom particles reaching Barrow in the fall (SeptemberOctober) and spring (May-June), for AG, SS and BS seeding

\begin{tabular}{|ccccccc|}
\hline Scenario & $\begin{array}{c}\text { Abundance AG (\#) } \\
\text { Sept-Oct Apr-May }\end{array}$ & $\begin{array}{c}\text { Abundance SS (\#) } \\
\text { Sept-Oct }\end{array}$ & \multicolumn{2}{c|}{$\begin{array}{c}\text { Abundance BS (\#) } \\
\text { Sept-Oct Apr-May }\end{array}$} \\
\hline 1997 & 49 & 348 & 107 & 37 & 74 & 101 \\
1998 & 169 & 195 & 414 & 230 & 167 & 100 \\
2002 & 489 & 375 & 754 & 111 & 245 & 162 \\
2003 & 213 & 223 & 54 & 39 & 62 & 117 \\
\hline
\end{tabular}


Table 4. May to October mean Bering Strait northward transport (Sv) from surface to bottom and from $20 \mathrm{~m}$ to bottom, and abundance of Year 1 bottom particles in the fall (September-October) at Barrow for BS simulations

\begin{tabular}{cccc} 
Scenario Transport & Transport 20 m- \\
(Sv) & bottom (Sv) & $\begin{array}{c}\text { Fall abundance } \\
\text { for BS simulation (\#) }\end{array}$ \\
\hline 1997 & 0.655 & 0.269 & 34 \\
1998 & 0.736 & 0.289 & 143 \\
2002 & 0.697 & 0.284 & 200 \\
2003 & 0.667 & 0.279 & 37 \\
\hline
\end{tabular}

wind alone can be a predictor of euphausiid abundance at Barrow in the fall.

The proportion of particles going through $\mathrm{CV}+\mathrm{CC}$ and $\mathrm{HV}$ is the second factor that influences the fall abundance. In this case the question is what drives particles toward one path or the other. Since the transport from the Chirikov Basin to $\mathrm{CV}$ or $\mathrm{HV}$ is mostly northward, particles on the eastern side of the basin are more likely to take the eastern path (CV or CC) than the HV pathway (data not shown). Subsequently, eastward Ekman transport, generated by winds from the south in the region from the Chirikov Basin to approximately $68^{\circ} \mathrm{N}$ (where the flow divides into $\mathrm{CV}$ and HV), favors higher fall abundance at Barrow. South wind events that mostly occur from late spring to summer in the Chukchi Sea partly explain the higher abundance of euphausiids in 2002 compared to 1998 (Fig. 9). On the contrary, strong northerly wind events, as in 1998, can potentially drive particles to CV instead of HV. This segregation between $\mathrm{HV}$ and $\mathrm{CV}$ could also favor SS-originating against AG-originating euphausiids at Barrow when strong NE winds prevail during summer (compare Figs. 6 \& 8 for 1998).

Although we do not intend to confirm the role of the factors proposed on the basis of $4 \mathrm{yr}$, these 2 simple causes (northward transport and east/west Ekman transport) appear to be robust and could be used to reconstruct the potential abundance of Year 1 euphausiids in the fall, if Bering Strait transport and April to October wind forcing, or only the wind over the Chukchi Sea is known. According to this analysis, it appears difficult to forecast the fall abundance from the previous winter conditions (e.g. the Arctic oscillation index), since the transport mostly depends on the April to October wind forcing.

Another factor, independent of the transport, that impacts the fall abundance is the timing of the ice retreat, which in turn influences the onset of spawning through phytoplankton availability (Ponomareva 1963, Siegel 2000a). If we consider that spawning at BS corresponds to an early ice retreat (Bering Strait is ice-free in May) while spawning at AG and SS corresponds to a late ice retreat (still ice in June at AG or SS), Figs. 6 to 8 suggest that an early ice retreat would result in a peak of abundance in the fall, while a late ice retreat would delay the peak to the following spring-summer period, with Year 2 euphausiids dominating during the next fall. Further analysis is needed to accurately quantify the sensitivity of the abundance to the iceretreat timing.

The variation of abundance of Year 2 euphausiids in the spring and fall is obviously more complex. Year 2 euphausiids are traveling through $\mathrm{CV}, \mathrm{CC}$ and $\mathrm{HV}$ pathways. As for Year 1 fall arrivals, Year 2 spring arrivals are impacted by the previous summer conditions for winds and Bering Strait transport. They are also influenced by the highly variable winter flow, and by the eastward-flowing along-slope current that interacts with the Herald Valley outflow and may or may not bring particles to Barrow. Also, the mortality of euphausiids due to predation and/or starvation during a 10 to 12 mo period can potentially deplete the stock arriving in the spring. These factors make the Year 2 euphausiid abundance variations harder to disentangle on a 4 yr basis; further analysis and a longer time-series are needed.

\section{CONCLUSIONS}

The motivation for this work was a better understanding of the interactions between the ocean circulation and the availability of bowhead whale prey in the Chukchi-Beaufort Seas. We focused on the main whale prey at Barrow, euphausiids, and examined the hypothesis of their transport from the Bering Sea to Barrow and the implications of this scenario. Our results show that most bottom euphausiids entering the Chukchi Sea will eventually pass through the Barrow region. Barrow is therefore a privileged area for bowhead whale feeding and hunting. Euphausiids can originate from both the northwestern and northeastern Bering shelves, although Anadyr Gulf appears to be the more probable source region because of higher euphausiid concentrations. The transport of euphausiids to Barrow is 4 to 5 times more likely to occur within topographically steered bottom layers than within surface layers. Since euphausiids should preferentially remain deeper in the water column (Ponomareva 1963), their transport to Barrow should be more efficient compared to transport of plankton in surface waters. To arrive at Barrow, euphausiids follow 2 main pathways: $\mathrm{CV}$, implying a short transit time and arrival in the fall and spring of the following year; and $\mathrm{HV}$, implying a long transit time and arrival in the spring of the following year. Arrivals have 2 peaks, the first at 146 to $192 \mathrm{~d}$ (BS) and 201 to $240 \mathrm{~d}$ (ca. 6 to $7 \mathrm{mo}$ ) (AG) 


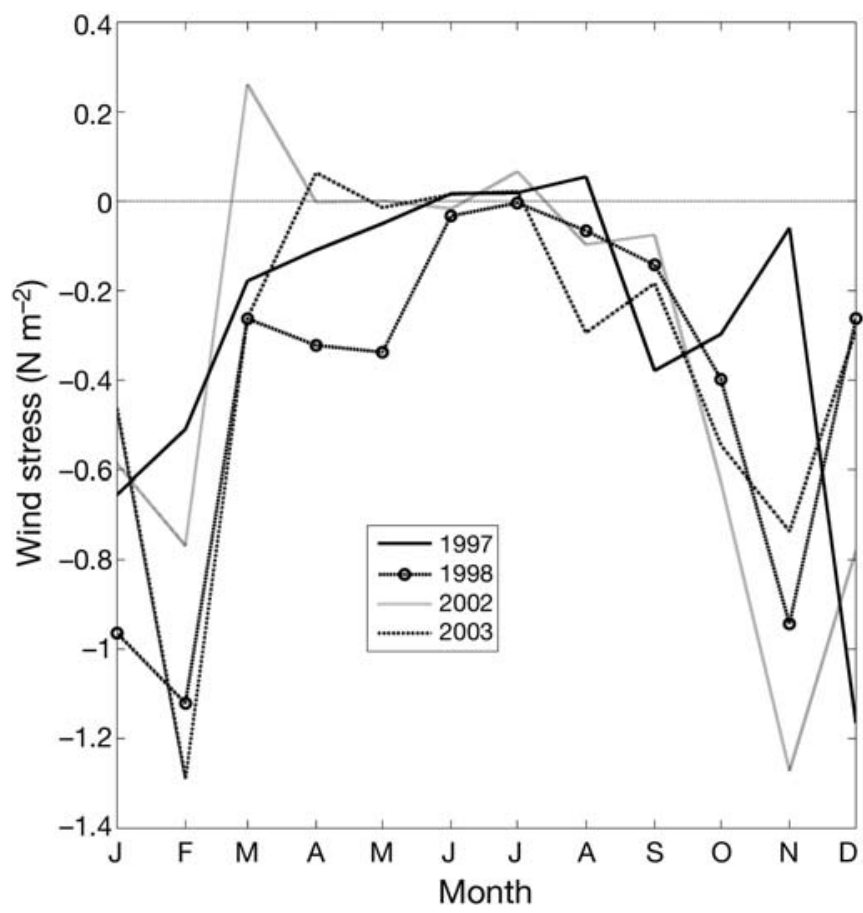

Fig. 9. Annual cycle of the monthly mean northward wind stress, positive northward) from the European Center for Medium Range Weather Forecasting for the 4 circulation scenarios. Values are averaged on a region covering $66-70^{\circ} \mathrm{N}, 165.5-172.5^{\circ} \mathrm{W}$

after release, the second at 361 to $412 \mathrm{~d}$ (BS) and 401 to $445 \mathrm{~d}$ (ca. 13 to $14 \mathrm{mo}$ ) (AG) on average after release. The DVM simulations produced the same pathways, and probabilities of reaching Barrow intermediate between surface and bottom simulations and ca. 15\% longer transit times compared to bottom simulations. It should be noted that transit times computed from current-meter observations suggest a ca. $25 \%$ overestimation of the simulated bottom transit times.

According to these transit times, observed euphausiid arrival in the spring at Barrow requires overwintering and survival on the ice-covered Chukchi shelf. Then euphausiids would seem well adapted to the Chukchi Sea, and the only evidence lacking to consider them as endemic to the Chukchi is their reproduction. Also, an interesting finding is that the number of euphausiids arriving at Barrow is maximal in spring and fall, corresponding to the periods of whale migration along Barrow shores. This suggests that prey availability near Barrow could drive the local whale migration timing; during periods of high euphausiids abundance whales may remain in the area to feed for longer periods of time. This also supports the hypothesis that whale feeding in spring is not occasional but significant as proposed by Lowry et al. (2004). Finally, euphausiid abundance in the fall at Barrow is found to be favored by a large northward transport and south winds events from April to October. Moore \& Laidre (2006) proposed that a reduction in sea-ice cover would favor a higher transport of prey through the Bering Strait. Here we did not find a clear ice cover impact, although a high ice cover clearly reduces the coupling between winds and currents.

In order to relate the real-world bowhead whale prey availability near Barrow to the euphausiid abundance from our transport experiments, we need to keep in mind the model assumptions, which should be revisited when additional field measurements are available. In the model, large scale transport has to be directly responsible for the availability of euphausiids to the whales. However, euphausiid aggregation near the coast can occur at scales (m to km, Mauchline 1980, Moore et al. 1995) smaller than those represented by the model resolution $(9 \mathrm{~km})$. Another assumption is that interannual variation at Barrow is due to the transport only and not to the variation of prey abundance in the source regions. Significant interannual variations of euphausiid production are related to food availability and water temperature in the Barents and Bering Seas (Smith 1991, Siegel 2000b). Therefore, euphausiid abundance at Barrow can be a combination of factors, and a more complex approach is needed to understand fully the abundance variability. Also, in the present modeling effort we assume that the mortality of euphausiids is zero. Mortality during transport may be caused by predation and/or starvation. No information is available on predation rates of euphausiids in our study region, although some authors suggest a 40 to $50 \%$ loss between 1 and $2 \mathrm{yr}$ old individuals in the northern Bering and Barents Seas (Ponomareva 1963, Siegel 2000a). If we apply this rate to the simulations, it would decrease the spring and summer euphausiid abundance, and suppress arrivals after the second year. Finally, although the representation of the Chukchi Sea circulation is qualitatively consistent with observational (Weingartner et al. 2005, Woodgate et al. 2005a) and modeling studies (Winsor \& Chapman 2004, Spall 2007), the Alaskan Coastal Current (ACC) is potentially not fully resolved by the model at this resolution. Therefore the very short ACC pathway, which could bring euphausiids to Barrow early in the fall, is potentially underestimated in the simulations. This should, however, have limited impact on the euphausiid abundance at Barrow since zooplankton concentration is supposed to be very low in the ACC (Springer et al. 1989).

The only data source that we presently have to validate the simulated interannual variability of euphausiid abundance at Barrow is the stomach content analysis of whales harvested at Barrow (Lowry et al. 2004, J. C. George \& G. Sheffield unpubl. data). Data include estimates of the volume of prey in the whale stomach and 
the composition of prey from the gut samples. Comparison with the model simulation is extremely difficult as the number of samples is very low and the relationship between stomach contents and euphausiid abundance in the water column is still subject to large uncertainties. Stomach content analysis of spring harvest whales also shows abundant concentration of copepods in addition to euphausiids. Therefore, to understand the whale prey availability, the local production of copepods should also be modeled.

Acknowledgements. Three anonymous reviewers are thanked for their helpful comments. L. Berline thanks J. Richman for providing the opportunity to present some of these results to students at OSU. We thank J. C. George of the North Slope Borough Department of Wildlife Management for reviewing this manuscript, and him and G. Sheffield of the Alaska Department of Fish and Game for unpublished information on whale stomach contents at Barrow and Kaktovik. S. Okkonen is thanked for his careful reading and suggestions. This work was supported by NSF grant \# OPP-0435956.

\section{LITERATURE CITED}

Aagaard K, Roach AT, Schumacher JD (1985) On the winddriven variability of the flow through Bering Strait. J Geophys Res 90:7213-7221

Astthorsson OS, Gislason A (1997) Biology of euphausiids in the subarctic waters north of Iceland. Mar Biol 129: 319-330

Berkes F (1976) Ecology of euphausiids in the Gulf of St. Lawrence. J Fish Res Board Can 33:1894-1905

Clement JL, Maslowski W, Cooper L, Grebmeier J, Walczowski W (2005) Ocean circulation and exchanges through the northern Bering Sea: 1979-2001 model results. Deep-Sea Res II 52:3509-3540.

Coachman LK, Aagaard K, Tripp RB (1975) Bering Strait: the regional physical oceanography. University of Washington Press, Seattle, WA

Cooney RT (1981) Bering Sea zooplankton and micronekton communities with an emphasis on annual production. In: Hood DW, Calder JA (eds) The eastern Bering Sea Shelf: oceanography and resources. University of Washington Press, Seattle, WA, p 947-974

Cooney RT, Coyle KO (1982) Trophic implications of crossshelf copepod distributions in the southeastern Bering Sea. Mar Biol 70:187-196

Dalpadado P, Skjoldal HR (1991) Distribution and life history of krill from the Barents Sea. Polar Res 10:443-460

Dalpadado P, Skjoldal HR (1996) Abundance, maturity and growth of the krill species. Thysanoessa inernis and $T$. longicaudata in the Barents Sea. Mar Ecol Prog Ser 144: 175-183

Einarsson H (1945) Euphausiacea: 1. Northern Atlantic species. Dana Rep, No. 27

Fach BA, Hofmann EE, Murphy EJ (2002) Modeling studies of antarctic krill Euphausia superba survival during transport across the Scotia Sea. Mar Ecol Prog Ser 231:187-203

Falk-Petersen S, Hopkins CCE (1981) Ecological investigations on the zooplankton community of Balsfjorden, northern Norway: population dynamics of the euphausiids Thysanoessa inermis (Krøyer), Thysanoessa raschii (M. Sars) and Meganyctiphanes norvegica (M. Sars) in 1976 and 1977. J Plankton Res 3:177-192

George JC, Zeh J, Suydam R, Clark C (2004) Abundance and population trend (1978-2001) of western Arctic bowhead whales surveyed near Barrow, Alaska. Mar Mamm Sci 20:755-773

Grebmeier JM, Harvey HR (2005) The Western Arctic ShelfBasin Interactions (SBI) project: an overview. Deep-Sea Res II 52:3109-3115

Hill VJ, Cota GF (2005) Spatial patterns of primary productivity in the Chukchi Sea in the spring and summer of 2002. Deep-Sea Res II 52:3344-3354

Hofmann EE, Klinck JM, Locarnini RA, Fach BA, Murphy EJ (1998) Krill transport in the Scotia Sea and environs. Antarct Sci 10(4):406-415

Johnson MW (1958) Observations on inshore plankton collected during summer 1957 at Point Barrow, Alaska. J Mar Res 17:272-281

Johnson MW (1963) Zooplankton collections from the High Polar Basin with special reference to the Copepoda. Limnol Oceanogr 8:89-102

Jorgensen C, Matthews JBL (1975) Ecological studies on the deep-water pelagic community of Korsfjorden, western Norway. Population dynamics of six species of euphausiids in 1968 and 1969. Sarsia 59:67-84

Kulka DW, Corey S (1978) The life history of Thysanoessa inermis in the Bay of Fundy. Can J Zool 56:492-506

Lane PVZ, Llinás L, Smith SL, Pilz D (2008) Zooplankton distribution in the western Arctic during summer 2002: hydrographic habitats and implications for food chain dynamics. J Mar Syst 70:97-133

Lowry LF (1993) Foods and feeding ecology. In: Burns JJ, Montague JJ, Cowles CJ (eds) The bowhead whale. Soc Mar Mamm Spec Publ 2, p 201-238

Lowry LF, Sheffield G (2002) Stomach contents of bowhead whales harvested in the Alaskan Beaufort Sea. In: Richardson WJ, Thomson DH (eds) Bowhead whale feeding in the eastern Alaskan Beaufort Sea: update of scientific and traditional information. OCS Study MMS 2002-012, LGL Rep TA2196-7, available from National Technical Information Service, Springfield, VA, Rep No. NTIS PB2004-101568, p 61-44

Lowry LF, Sheffield G, George JC (2004) Bowhead whale feeding in the Alaskan Beaufort Sea, based on stomach contents analyses. J Cetacean Res Manage 6:215-223

> Maslowski W, Marble D, Walczowski W, Schauer U, Clement JL, Semtner AJ (2004) On climatological mass, heat, and salt transports through the Barents Sea and Fram Strait from a pan-Arctic coupled ice-ocean model simulation. J Geophys Res 109:C03032, doi:10.1029/ 2001JC001039

Mauchline J (1980) The biology of mysids and euphausiids. Adv Mar Biol 18:1-681

Moore SE, Clarke JT (1992) Patterns of bowhead whale distribution and abundance near Barrow, Alaska, in fall 19821989. Mar Mamm Sci 8:27-36

Moore SE, Laidre KL (2006) Trends in sea ice cover within habitats used by bowhead whales in the western Arctic. Ecol Appl 16:932-944

Moore SE, Reeves RR (1993) Distribution and movement. In: Burns JJ, Montague JJ, Cowles CJ (eds) The bowhead whale. Soc Mar Mamm Spec Publ 2, p 313-386

Moore SE, George JC, Coyle KO, Weingartner TJ (1995) Bowhead whales along the Chukotka coast in autumn. Arctic 48:155-160

Moore SE, Demaster DP, Dayton PK (2000) Cetacean habitat selection in the Alaskan Arctic during summer. and autumn. Arctic 53:432-447 
Murphy EJ, Watkins JL, Reid K, Trathan PN and others (1998) Interannual variability of the South Georgia marine ecosystem: biological and physical sources of variation in the abundance of krill. Fish Oceanogr 7(3/4):381-390

Niebauer HJ, Schell DM (1993) Physical environment of the Bering Sea population. In: Burns JJ, Montague JJ, Cowles CJ (eds) The bowhead whale. Soc Mar Mamm Spec Publ 2, p 201-238

North Pacific Anadromous Fish Commission (2004) Annual report of the Bering-Aleutian Salmon International Survey (BASIS), 2003. NPAFC Doc. 769. BASIS Working Group, North Pacific Anadromous Fish Commission, Vancouver, BC

North Pacific Anadromous Fish Commission (2005) Annual report of the Bering-Aleutian Salmon International Survey (BASIS), 2004. NPAFC Doc. 857. BASIS Working Group, North Pacific Anadromous Fish Commission, Vancouver, $\mathrm{BC}$

Piatt JF, Springer AM (2003) Advection, pelagic food webs and the biogeography of seabirds in Beringia. Mar Ornithol 31:141-154

Pickart RS, Weingartner TJ, Pratt LJ, Zimmermann S, Torres DJ (2005) Flow of winter-transformed Pacific water into the Western Arctic. Deep-Sea Res II 52:3175-3198

Ponomareva LA (1963) The euphausiids of the North Pacific, their distribution and ecology. Akad Nauk, SSSR, Inst Okeanol, translated by Israel Program for Scientific Translations, Jerusalem (1966)

Roach AT, Aagaard K, Pease CH, Salo SA, Weingartner TJ, Pavlov V, Kulakov M (1995) Direct measurements of transport and water properties through Bering Strait. J Geophys Res 100:18443-18457

Schell DM, Barnett BA, Vinette KA (1998) Carbon and nitrogen isotope ratios in zooplankton of the Bering, Chukchi and Beaufort seas. Mar Ecol Prog Ser 162:11-23

Siegel V (2000a) Krill (Euphausiacea) life history and aspects of population dynamics. Can J Fish Aquat Sci 57 (Suppl. 3):130-150

Siegel V (2000b) Krill (Euphausiacea) demography and variability in abundance and distribution. Can J Fish Aquat Sci 57(Suppl. 3):151-167

Smith RD, Gent PR (2004) Reference manual for the Parallel Ocean Program (POP). Los Alamos National Laboratory Tech Rep LA-UR-02-2484

Smith SL (1991) Growth, development and distribution of the euphausiids Thysanoessa raschii (M. Sars) and Thysanoessa inermis (Kroyer) in the southeastern Bering Sea.

Editorial responsibility: Matthias Seaman, Oldendorf/Luhe, Germany
Polar Res 10:461-478

Spall MA (2007) Circulation and water mass transformation in a model of the Chukchi Sea. J Geophys Res 112:C05025, doi:10.1029/2005JC002264

Springer AM, McRoy CP, Turco K (1989) The paradox of pelagic food webs in the northern Bering Sea - II. Zooplankton communities. Cont Shelf Res 9:359-386

Springer AM, McRoy CP, Flint MV (1996) The Bering Sea Green Belt: shelf-edge processes and ecosystem production. Fish Oceanogr 5:205-223

> Thompson DWJ, Wallace JM (1998) The Arctic Oscillation signature in the wintertime geopotential height and temperature fields. Geophys Res Lett 25:1297-1300

Thorpe SE, Heywood KJ, Stevens DP, Brandon MA (2004) Tracking passive drifters in a high resolution ocean model: implications for interannual variability of larval krill transport to South Georgia. Deep-Sea Res 51(7):909-920

$>$ Timofeev SF (2000) Discovery of eggs and larvae of Thysanoessa raschii (M. Sars, 1846) (Euphausiacea) in the Laptev Sea: proof of euphausiids spawning on the shelf of the Arctic Ocean. Crustaceana 73:1089-1094

Walsh JJ, Mcroy CP, Coachman LK, Goering JJ and others (1989) Carbon and nitrogen cycling within the Bering/ Chukchi Seas: source regions for organic matter affecting AOU demands of the Arctic Ocean. Prog Oceanogr 22: 277-359

- Weingartner TJ, Cavalieri DJ, Aagaard K, Sasaki Y (1998) Circulation, dense water formation, and outflow on the northeast Chukchi shelf. J Geophys Res 103: $7647-7661$

Weingartner TJ, Aagaard K, Woodgate RA, Danielson S, Sasaki Y, Cavalieri DJ (2005) Circulation on the north central Chukchi Sea shelf. Deep-Sea Res II 52:3150-3174

Wiborg KF (1971). Investigations on euphausiids in some fjords on the west coast of Norway 1966-1969. Fiskeridir Skr Ser Havunders 16:10-35

Winsor P, Chapman DC (2004) Pathways of Pacific water across the Chukchi Sea: a numerical model study. J Geophys Res 109:C03002, doi:1029/2003JC001962

Woodgate RA, Aagaard K, Weingartner TJ (2005a) A year in the physical oceanography of the Chukchi Sea: moored measurements from autumn 1990-1991. Deep-Sea Res II 52:3116-3149

Woodgate RA, Aagaard K, Weingartner TJ (2005b) Monthly temperature, salinity, and transport variability of the Bering Strait throughflow. Geophys Res Lett 32:L04601, doi:10.1029/2004GL021880

Submitted: August 16, 2007; Accepted: December 20, 2007 Proofs received from author(s): May 14, 2008 